\title{
Bagaimana Remaja Menjadi Peer-Counselor di Masa Pandemi?
}

\author{
(How Teenagers being Peer-Counselor during Pandemic?)
}

\author{
Nina Permatasari1*, Eklys Cheseda Makaria1, Irene Maya Simon², Muhammad Andri \\ Setiawan' 1 \\ ${ }^{1}$ Universitas Lambung Mangkurat, Jl. Kayutangi, Banjarmasin, Kalimantan Selatan, Indonesia \\ 2Universitas Negeri Malang, Jl. Semarang No. 5 Malang, Jawa Timur, Indonesia \\ *Penulis korespondensi, Surel: nina.bk@ulm.ac.id
}

Paper received: 8th-Feb-2021; revised: 28th-Feb-2021; accepted: 10th-Mar-2021

\begin{abstract}
To optimally carry out their developmental tasks during the Covid-19 Pandemic, which affects psychosocial and mental health, teenagers require mentoring. One of those accompaniments may come from their peers. This study observes the way teenagers being peer-counselors during the Covid-19 pandemic. This quantitative research uses a descriptive survey design. Meanwhile, its populations were all participants of peer counseling training webinars conducted by the Centre of Guidance and Counselling Service of Lambung Mangkurat University. The 126 samples were selected using a random sampling technique live in South Borneo. The results convey that 32\%, 78\%, and $58 \%$ of teenagers actively being peer-counselors at the age of 16 years, at the high school age, and when the pandemic started, respectively. A $40 \%$ of teenagers explain that they choose to be peer counselors because they like to help their friends, $53 \%$ of them feel to have a superior personality that supports them to be peer counselors, while $27 \%$ of them contemplate on things they can suggest to help their friends as peer counselors. Additionally, 54\% of teenagers wish to attain peer counselors' skills that can command the counselees' thoughts. Thus, teenagers have given relatively significant contributions as peer counselors during the Covid-19 pandemic.
\end{abstract}

Keywords: adolescent; peer counselor; pandemic; covid-19

\begin{abstract}
Abstrak
Guna melaksanakan tugas perkembangan dengan optimal selama pandemi covid-19 yang berdampak pada kesehatan mental dan kondisi psikososial, remaja perlu pendampingan. Salah satunya adalah pendampingan dari teman sebaya. Tujuan penelitian ini adalah mendapatkan gambaran mengenai bagaimana remaja menjadi konselor sebaya di masa pandemic covid-19. Penelitian kuantitatif ini menggunakan desain survei-deskriptif. Populasi penelitian merupakan seluruh peserta webinar pelatihan konseling teman sebaya yang diadakan oleh Pusat Layanan Bimbingan dan Konseling (PLBK) Universitas Lambung Mangkurat. Teknik penarikan sampel menggunakan teknik total random sampling yaitu sebanyak 126 sampel yang berdomisili di Kalimantan Selatan. Hasil menunjukkan bahwa 32 persen remaja aktif menjadi konselor sebaya pada usia 16 tahun, 78 persen mulai SMA/SMK, 58 persen mulai pada masa pandemi. Empat puluh persen remaja beralasan menjadi konselor sebaya karena merasa senang dapat membantu temannya, 53 persen merasa memiliki kepribadian yang unggul sebagai konselor sebaya karena terdorong untuk membantu, 27 persen memiliki pikiran apakah yang bisa saya sarankan kepada teman saya disaat menjadi konselor sebaya dan 54 persen ingin mendapatkan keterampilan sebagai konselor sebaya yang mampu mengendalikan pikiran konseli. Dapat disimpulkan bahwa remaja sudah berperan cukup baik menjadi konselor sebaya di masa pandemik covid-19.
\end{abstract}

Kata kunci: remaja; peer counselor; masa pandemi; covid-19 


\section{Pendahuluan}

Pandemi covid-19 yang merupakan bencana non alam yang berdampak pada kesehatan mental dan kondisi psikososial. WHO (2020) turut menguatkan bahwa pandemi menyebabkan stres pada berbagai lapisan masyarakat, terutama pada peserta didik tingkat Sekolah Dasar, Sekolah Menengah dan Perguruan tinggi selama berlangsungnya pembelajaran daring di masa pandemi covid-19.

Data dari WHO dan survei kesehatan nasional Indonesia (Kemenkes RI, 2013; Soerachman, 2007; WHO, 2014) bahwa setengah gangguan kesehatan mental yang cukup parah dimulai pada remaja sejak usia 14 tahun. Ditemukan dari hasil beberapa riset kepada remaja usia sekolah akibat dari pandemi covid-19 terhadap kesehatan mental mereka, ada empat kategori dampak yang terjadi, yaitu: (1) dampak pada aspek kesehatan; mengalami gangguan tidur, sakit kepala, tegang, meningkatnya detak jantung, mudah kelelahan, berkurangnya nafsu makan dan gangguan lambung/pencernaan, (2) dampak pada aspek kognitif; mengalami penurunan daya ingat, kurang mampu berkonsentrasi, kebingungan dan disonansi kognitif, (3) dampak pada aspek emosi; mengalami ketidakseimbangan emosi, murung, sedih, kecewa, menjadi lebih sensitif, frustasi, mudah marah, cemas, minat belajar menurun, stres akademik, depresi bahkan keinginan bunuh diri karena merasa tidak berdaya, dan, (4) dampak pada aspek perilaku; menurunnya dorongan untuk bersosialisasi, lebih suka menyendiri di dalam kamar, malas untuk beraktivitas, menjadi pendiam, perilaku kecanduan gawai. Gejala-gejala tersebut dikarenakan sumber kesenangan terbatas pada aktivitas di dalam ruangan, menghabiskan banyak waktu menonton televisi dan bermain gawai yang menyebabkan kecanduan perilaku. Implementasi pembelajaran daring yang kurang lancar dikarenakan gangguan sinyal, kemampuan ekonomi siswa untuk membeli kuota data internet, alat informatika dan teknologi (IT) yang dimiliki kurang lengkap serta terlalu lamanya mereka harus karantina di rumah selama berbulan-bulan (Russell, 2010; Kar et al., 2020; O'Sullivan \& Bourgoin, 2010; Sari, 2017; Yao, Chen, \& Xu, 2020).

Remaja pada rentang usia 13-21 tahun cenderung lebih terbuka pada teman sebayanya dibandingkan dengan orangtua atau orang dewasa dalam menghadapi permasalahannya (Carandang et al., 2019; Kandah, 2017; Rahmawati \& Suwarjo, 2019). Remaja membutuhkan teman yang bisa mendampingi tugas-tugas perkembangan dengan baik dan menyelesaikan masalah mereka melalui teman sebaya, konselor sebaya berfungsi lebih baik karena dapat menjangkau khalayak sosial yang lebih luas (Schmidt, 2013). Sebuah hasil penelitian menunjukkan bahwa konseling lebih efektif pada konselor teman sebaya dibandingkan konseling kepada guru atau orangtua (Carandang et al., 2019). Konselor sebaya bukan konselor atau terapis profesional, namun konselor sebaya adalah siswa/mahasiswa yang memiliki usia yang sama (remaja), untuk membantu permasalahan psikologis yang dialami temannya dengan dibawah bimbingan konselor ahli, sehingga keterampilan dasar konseling bagi remaja perlu dimiliki oleh konselor sebaya berdampak positif pada keberhasilan proses konseling teman sebaya (Rahmawati \& Suwarjo, 2019; Sari, 2017).

Mengingat cukup besarnya peran remaja sebagai konselor sebaya untuk membantu para remaja lain yang mengalami masalah psikologis di masa pandemi covid-19 ini, perlu analisis lebih lanjut tentang kesiapan para remaja dalam membantu mengentaskan persoalanpersoalan yang dialami oleh teman-teman sebayanya. Corey, (2009) menyatakan bahwa ada tiga kondisi inti untuk menciptakan iklim yang kondusif dalam proses konseling kesesuaian, suka rela/ memberikan bantuan tanpa syarat dan empati. Kode etik kerahasiaan juga 
merupakan hal penting yang harus diketahui oleh konselor sebaya, yaitu sebuah kode moral yang menjadi landasan bekerja untuk profesional. Meskipun konselor sebaya tidak profesional, untuk memastikan keamanan dan kenyamanan konseli dan menjaga citra baik profesional konselor, oleh karenanya konselor sebaya perlu memiliki kode etik. Hal ini menarik untuk ditelusuri lebih jauh bagaimanakah remaja menjadi konselor sebaya di masa pandemi covid19, melakukan bantuan layanan psikologis yang dibutuhkan pada remaja seusianya yang bermasalah di masa pandemi covid-19. Apabila hal ini tidak segera diatasi maka dapat mengakibatkan konsekuensi negatif jangka panjang yang signifikan, bahkan di masa pandemi covid-19 yang saat ini belum berakhir dan terus berkembang (Chafouleas \& Marcy, 2020; Minkos \& Gelbar, 2021; Pragholapati, 2020). Remaja memiliki kontribusi besar untuk membantu pertumbuhan kepribadian yang positif dan meningkatkan kesejahteraan kesehatan mental di dalam komunitas sebaya mereka serta sebagai agen strategis untuk mengarahkan dan membimbing kehidupan remaja ke arah yang lebih baik (Laila, Flurentin, \& Simon, 2019; Salmiati, Rosmawati, \& Lestari, 2018; Syarifah, 2020). Tujuan dalam penelitian ini adalah mendapatkan gambaran remaja menjadi konselor sebaya di masa pandemic covid-19.

\section{Metode}

Pendekatan dalam penelitian ini adalah pendekatan kuantitatif dengan desain penelitian menggunakan survei-deskriptif. Tujuan dari penelitian ini adalah untuk mendapatkan gambaran remaja menjadi konselor sebaya pada masa pandemi covid-19. Pengumpulan data menggunakan kuesioner yang disebarkan melalui Google-Form.

Tabel 1. Populasi Penelitian

\begin{tabular}{clc}
\hline No & Tingkat Sekolah & Populasi \\
\hline 1 & SMP/Sederajat & 9 \\
2 & SMA/SMK/Sederajat & 98 \\
3 & Universitas/ Sederajat & 9 \\
& Jumlah Total & 126 \\
\hline
\end{tabular}

Populasi penelitian diambil dari seluruh peserta webinar pelatihan konseling teman sebaya yang diadakan oleh Pusat Layanan Bimbingan dan Konseling (PLBK) Universitas Lambung Mangkurat pada tanggal 5 Desember 2020. Teknik penarikan sampel ini menggunakan total random sampling, dengan mengambil keseluruhan jumlah populasi untuk dijadikan sampel penelitian. Jumlah peserta sebanyak 126 orang dari berbagai lintas remaja tingkat SMP, SMA/SMK dan Perguruan tinggi yang di Kalimantan Selatan.

Data survei yang diidentifikasi pada kesiapan konselor sebaya dalam instrumen penelitian ini adalah usia, tingkat pendidikan, sudah berapa lama menjadi konselor sebaya, alasan menjadi konselor sebaya, kelebihan kepribadian menjadi konselor sebaya, pikiran yang muncul ketika menjadi konselor sebaya dan keterampilan yang ingin dipelajari/dikuasai menjadi konselor sebaya. Teknik analisis data menggunakan analisis statistik deskriptif persentase. 


\section{Hasil dan Pembahasan}

\subsection{Hasil}

\subsubsection{Gambaran Usia Remaja yang Menjadi Konselor Sebaya}

Gambar 1 menunjukkan bahwa responden penelitian ini terbagi ke dalam rentang usia 15-20 tahun. Secara rinci usia konselor sebaya dalam penelitian ini ada 32\% atau sebanyak 40 orang responden menjawab berusia 16 tahun; $22 \%$ atau 28 orang responden menjawab berusia 15 tahun; $19 \%$ atau 17 orang responden menjawab berusia 17 tahun; $12 \%$ atau 18 orang responden menjawab berusia 18 tahun; $10 \%$ atau 13 orang menjawab berusia 20 tahun; dan 5\% sisanya atau 6 orang menjawab berusia 19 tahun. Usia remaja yang menjadi konselor dalam rentang usia 16 tahun.

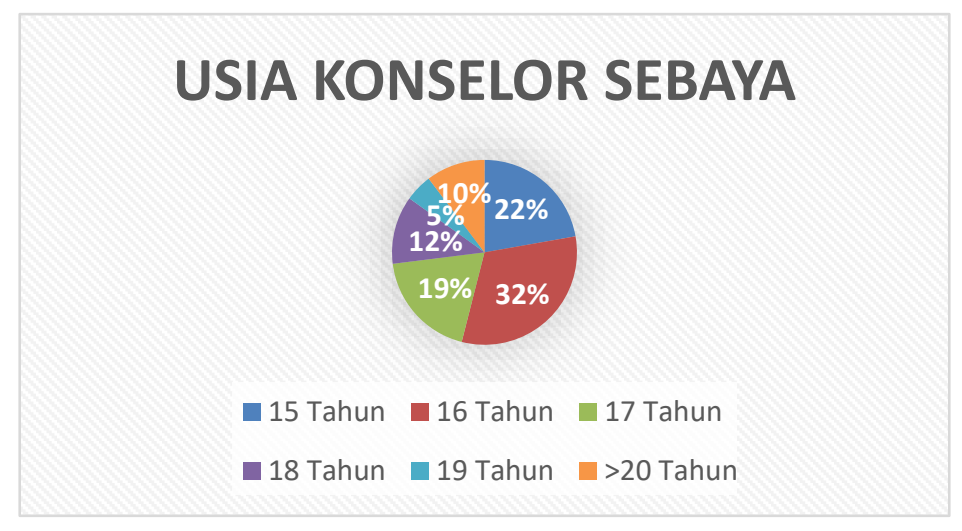

Gambar 1. Usia Konselor Sebaya

\subsubsection{Gambaran Tingkat Pendidikan Remaja yang Menjadi Konselor Sebaya}

Gambar 2 menunjukkan tingkat Pendidikan untuk konselor sebaya yang terbagi menjadi tiga, yaitu SMP sederajat, SMA/SMK sederajat, dan Universitas sederajat. Konselor sebaya dengan tingkat pendidikan SMP sederajat atau yang sedang menempuh pendidikan menengah atas sebanyak 7\% atau 9 orang. Konselor Sebaya yang sedang tingkat pendidikan SMA/SMK sederajat ada $78 \%$ atau 98 orang. Sebanyak 15\% sisanya, atau 19 orang responden menjawab tingkatan universitas sederajat. Tingkat pendidikan yang menjadi konselor berada pada tingkat SMA/SMK sederajat.

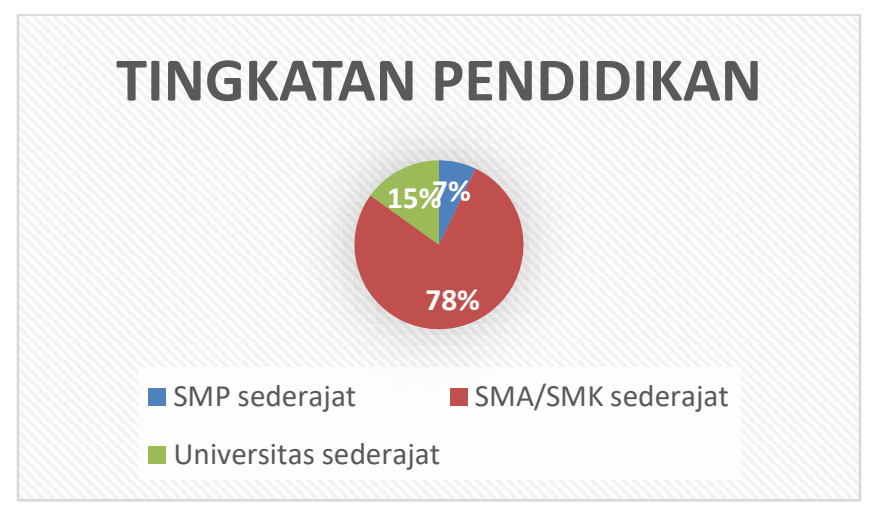

Gambar 2. Tingkat Pendidikan Konselor Sebaya 


\subsubsection{Gambaran Lama Remaja yang Menjadi Konselor Sebaya}

Gambar 3 menunjukkan durasi atau lamanya waktu seorang responden menjadi konselor sebaya. Jawaban responden bervariatif, dari yang tidak pernah menjadi konselor sebaya sampai lebih dari 2 tahun. Jawaban responden dapat dirinci sebagai berikut, ada 59\% atau 74 orang responden yang baru mau memulai menjadi konselor sebaya; sebanyak $27 \%$ atau 34 orang sudah menjadi konselor sebaya sekitar 1-2 tahun; sebanyak $11 \%$ atau 14 orang responden yang pernah menjadi konselor sebaya selama kurang dari 1 tahun; ada 2\% atau 3 orang yang tidak pernah sama sekali menjadi konselor sebaya, dan sisanya sebanyak $1 \%$ atau 1 orang yang pernah menjadi konselor sebaya lebih dari 2 tahun. Kebanyakan siswa yang terlibat merupakan siswa yang baru akan menjadi konselor sebaya.

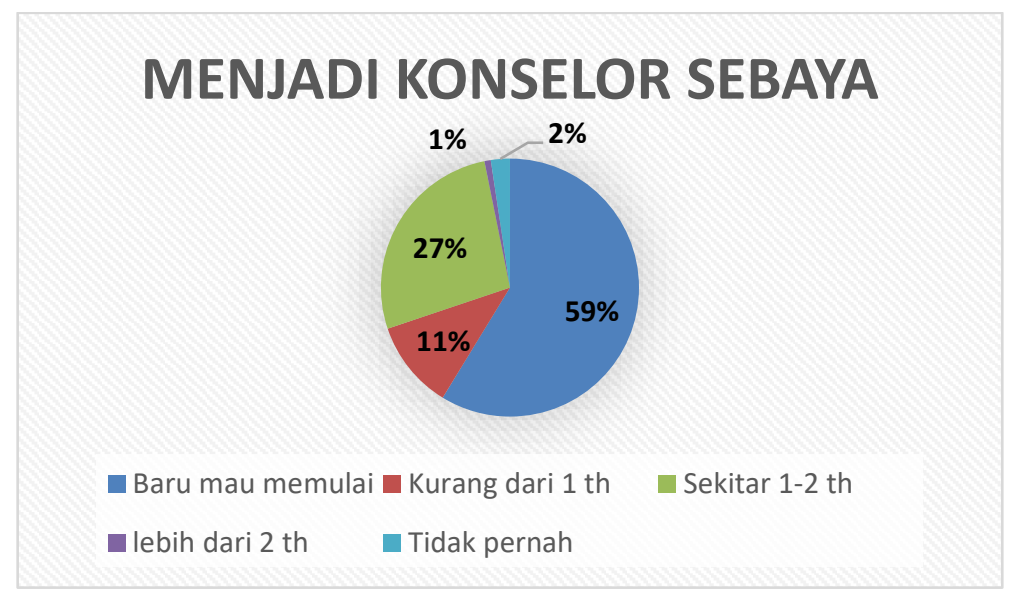

Gambar 3. Lama Menjadi Konselor Sebaya

\subsubsection{Gambaran Alasan Remaja Menjadi Konselor Sebaya}

Pada Gambar 4, diagram alasan menjadi konselor sebaya terbagi menjadi lima kategori, yaitu: (1) senang bila bisa membantu teman; (2) rasa ingin membantu teman; (3) banyak teman yang merasa nyaman ketika curhat dengan saya; (4) terinsipirasi oleh guru BK; (5) dipilih oleh guru BK/dosen; dan (6) alasan lainnya, seperti ingin mendapat pengalaman dan wawasan yang baru. Alasan-alasan tersebut dapat dirincikan sebagai berikut: sebanyak $40 \%$ atau 69 orang menjadi konselor sebaya karena merasa senang bila bisa membantu temannya. Ada $34 \%$ atau 59 orang responden yang menjadi konselor sebaya karena merasa ingin membantu teman yang memiliki masalah. Sebanyak $34 \%$ atau 29 orang respon menjadi konselor sebaya karena banyak teman-teman yang nyaman bercerita/curhat dengan dirinya. Sebanyak $17 \%$ atau 8 orang responden terinspirasi oleh guru BK yang membuat responden tersebut menjadi konselor sebaya. Sebanyak $5 \%$ atau 5 orang responden menjadi konselor sebaya dikarenakan dipilih oleh guru BK/dosen saya, dan sisanya sebanyak $4 \%$ menjadi kon selor sebaya karena alasan lainnya, seperti ingin mendapat wawasan dan pengalaman yang baru. Sebagian besar siswa yang mau menjadi konselor sebaya berkeinginan membantu teman dengan senang hati. 


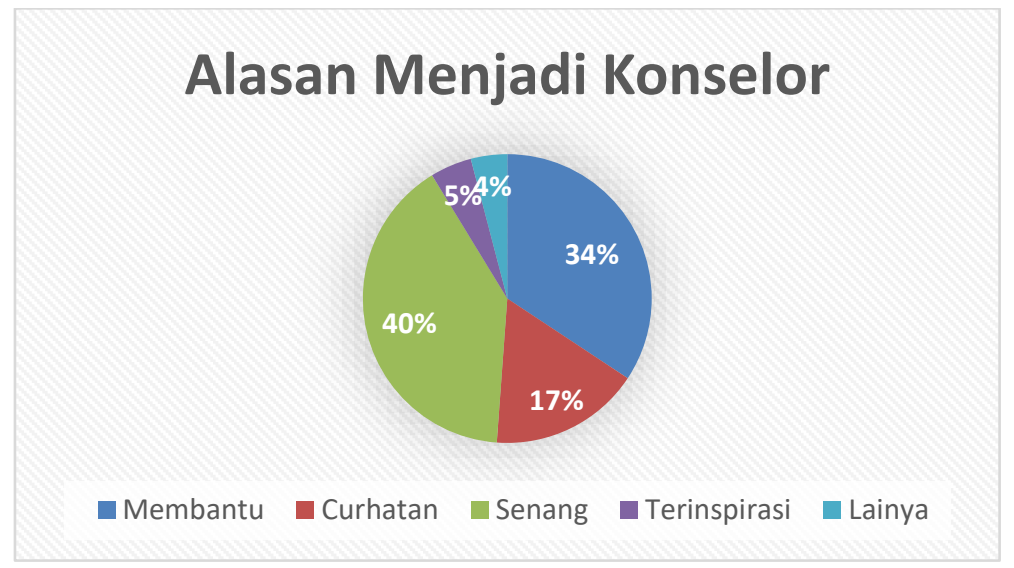

Gambar 4. Alasan Menjadi Konselor Sebaya

\subsubsection{Gambaran Kelebihan Kepribadian yang Dimiliki Remaja Menjadi Konselor Sebaya}

Gambar 5 yang berisi diagram gambaran kelebihan yang dimiliki remaja menjadi konselor sebaya terbagi menjadi tiga jenis kelebihan, yaitu: (1) pendengar yang baik; (2) termovitasi untuk membantu; dan (3) kelebihan lainnya. Jenis-jenis kelebihan kepribadian tersebut dalam dirincikan sebagai berikut. Sebanyak 82 orang atau 53\% responden menganggap konselor teman sebaya memiliki kelebihan yaitu memiliki motivasi untuk membantu. Sebanyak 71 orang atau 46\% responden menganggap konselor teman sebaya memiliki kelebihan sebagai pendengar yang baik, dan sisanya 2 orang atau $1 \%$ responden menganggap konselor sebaya dapat merespon cerita temannya dengan senang hati. Siswa yang mengikuti pelatihan konselor sebaya merasa memiliki kelebihan untuk memotivasi siswa lain yang membantunya

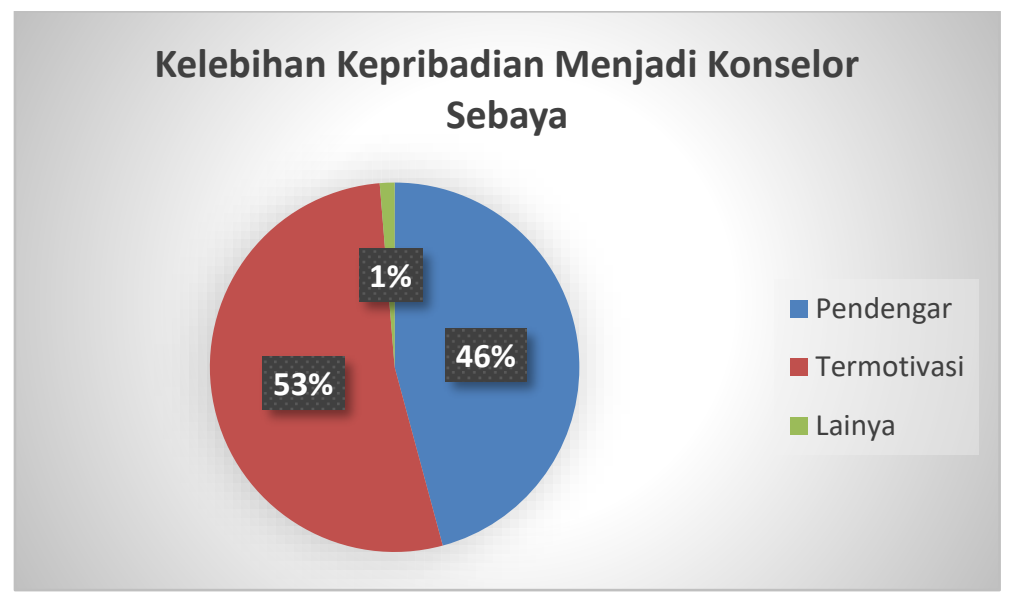

Gambar 5. Kelebihan Kepribadian Konselor Sebaya

\subsubsection{Gambaran Pikiran yang Muncul Ketika Menjadi Konselor Sebaya}

Gambar 6 berisi diagram gambaran pikiran yang muncul saat konseling dengan teman sebaya menunjukkan ada enam pikiran yang muncul, yaitu: (1) "apa yang bisa saya sarankan untuk dia?" sebanyak $27 \%$ atau 61 orang; (2) "apakah saya bisa membantu atau malah 
membuat masalah untuk dia?" sebanyak $24 \%$ atau 53 orang; (3) "bagaimana saya bisa membantunya?" sebanyak $19 \%$ atau 42 orang; (4) "bagaimana saya yakin bisa menolongnya?" sebanyak 15\% atau 34 orang; (5) "bagaimana saya harus memulai konseling?" sebanyak 6\% atau 14 orang; dan (6) "masalah dia berat atau tidak ya?" sebanyak 6\% atau 13 orang. Pikiran yang muncul dari siswa yang menjadi konselor sebaya adalah "apakah saya bisa membantu atau malah membuat masalah untuk dia?"

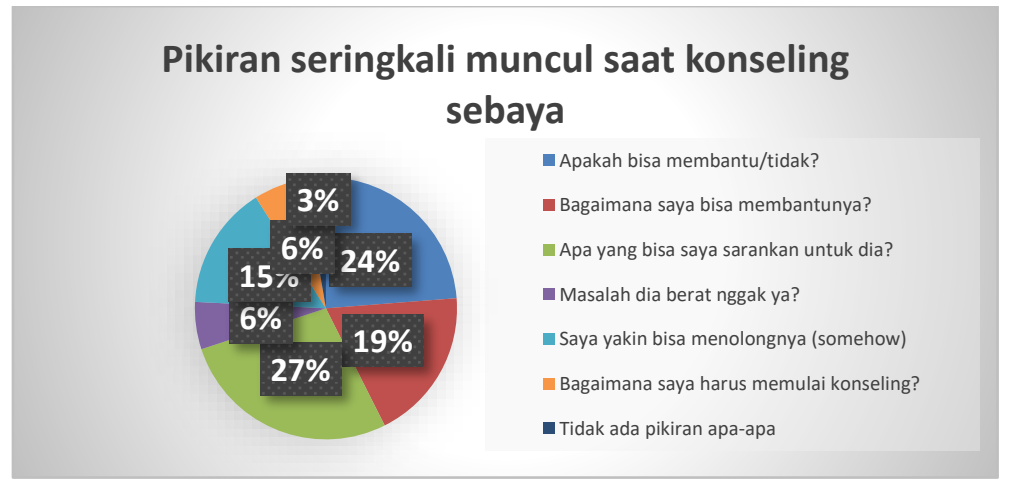

Gambar 6. Pikiran yang Muncul saat Konseling Sebaya

\subsubsection{Gambaran Keterampilan yang Ingin Dipelajari/Dikuasai Menjadi Konselor \\ Sebaya}

Keterampilan yang ingin dipelajari/dikuasai menjadi konselor sebaya terbagi menjadi empat jawaban, yaitu (1) mengendalikan pikiran sebanyak 54\% atau 90 orang; (2) prosedur konseling sebanyak 24\% atau 40 orang; (3) Teknik-teknik konseling sebanyak $21 \%$ atau 36 orang, dan (4) tidak ada pikiran apa-apa sebanyak 1\% atau 1 orang. Keterampilan yang diinginkan oleh siswa untuk dikuasai adalah mengendalikan pikiran.

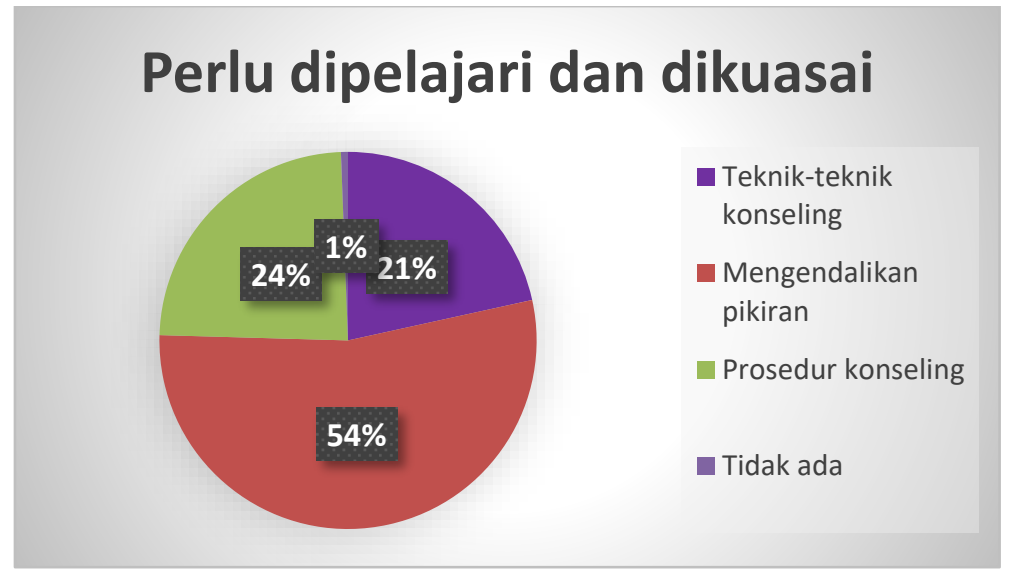

Gambar 7. Keterampilan yang Perlu Dipelajari dan Dikuasai Konselor Sebaya

\subsection{Pembahasan}

Tujuan konseling sebaya adalah membantu penyelenggaraan program bimbingan dan konseling, dengan menyediakan tenaga pendukung melalui pemanfaatan potensi dari kalangan siswa/mahasiswa sendiri untuk bisa saling menolong (Pandang, 2019). Gagasan awal konselor sebaya didasari oleh kuat dan pentingnya hubungan antar teman sebaya dalam 
kehidupan individu. Oleh karena itu, usia individu yang menjadi konselor sebaya berusia antara 15-20 tahun, yang masih termasuk dalam usia remaja. Perkembangan sosioemosional, perilaku dan kepribadian remaja yang baik dan normal sangat dipengaruhi oleh hubungan teman sebaya (Santrock, 2007; Sarmin, 2017). Hal ini didukung oleh fakta bahwa pada masa remaja, aspek sosial individu berkembang pesat, terutama dalam kelompok teman sebaya, terutama dalam jalinan persahabatan yang mulai muncul di usia-usia remaja.

Teman sebaya bagi remaja, adalah kelompok dengan rentang usia yang sama, yang dapat menjadi tempat untuk bertukar pikiran, bercerita, bergaul, dengan nyaman. Teman sebaya adalah individu dengan tingkat usia dan tingkat kedewasaan yang setara (Santrock, 2007). Kelompok teman sebaya menjadi salah satu strategi penting dalam bimbingan dan konseling, karena dalam usia-usia remaja, mereka sangat dekat dengan kelompok teman sebayanya (peer group). Hal ini dikarenakan remaja memerlukan pengakuan dan penerimaan dari kelompok sebayanya (Hurlock, 2005). Pendapat Hurlock mempertegas bahwa remaja lebih memilih menyampaikan dan mengekspresikan perasaan serta pikirannya kepada teman sebaya. Hal ini dikarenakan remaja beranggapan bahwa teman sebaya memiliki persamaan yang khas, dan dapat menerima dirinya, sehingga banyak remaja yang cenderung lebih suka mengungkapkan diri dan permasalahannya kepada teman-teman dekatnya.

Periode remaja terbagi dua, yaitu remaja awal dan remaja akhir (Santrock, 2007). Remaja awal, dengan rentang usia 10-13 tahun, dan remaja akhir dengan rentang usia 18-22 tahun. Rentang usia tersebut jika diselaraskan dengan jenjang pendidikan, maka dimulai dari jenjang Sekolah Menengah Pertama (SMP) dan berakhir pada jenjang Pendidikan Tinggi (PT). Siswa-siswa SMP dan SMA, serta mahasiswa-mahasiswa perguruan tinggi dapat menjadi konselor sebaya dengan seleksi dan latihan yang baik serta memadai (Upcraft, 1971). Konselor sebaya dapat bekerja efektif, sama efektifnya dengan konselor professional ketika masalah yang ditangani bukan masalah yang parah dan patologis, dan konselor sebaya dapat bekerja dengan sikap empatik, penghargaan positif serta kongruensi (Pandang, 2019).

Terdapat beberapa program dan kegiatan yang dapat diselenggarakan oleh siswa SMP atau SMA saat menjadi konselor sebaya. Beberapa kegiatan tersebut antara lain dengan tema menanggulangi pengaruh negatif lingkungan, kesehatan reproduksi remaja, mereduksi kecanduran game online, meningkatkan penerimaan diri, meningkatkan keterampilan interpersonal; pengembangan perilaku prososial (Hendrik \& Elmansyah, 2018; Husein, 2018; Indriyati, 2018; Ismiyati, Walessa, Sunjaya, \& Susanah, 2019; Prasetiawan, 2016; Sarmin, 2017). Berdasarkan penelitian-penelitian tersebut, konselor sebaya pada tingkat SMP atau SMA berpartisipasi dalam kegiatan konseling sederhana, pengembangan diri, bimbingan kelompok, terlibat dalam bimbingan klasikal. Jenjang pendidikan tinggi, konselor sebaya lebih pada membantu rekan mahasiswa dalam hal layanan orientasi dan penyesuaian diri bagi mahasiswa baru dengan lingkungan kampus, Latihan keterampilan dan evaluasi kebiasaan belajar bagi mahasiswa yang terancam DO (dropout), dan pemberian dukungan bagi mahasiswa minoritas (Pandang, 2019). Konseling sebaya dalam masa pandemi covid-19 terkait dengan kekhawatiran dan kecemasan konseli terhadap masa depan. Salah satu yang dapat dilakukan oleh konselor sebaya adalah relaksasi, dengan tujuan menstabilkan emosi (Syarifah, 2020).

Pandang (2019) membagi konselor sebaya menjadi tiga kelompok tingkatan, yaitu konselor sebaya pemula, konselor sebaya madya dan konselor sebaya senior. Pembagian ini 
berdasarkan lama waktu seorang siswa atau mahasiswa menjadi konselor sebaya. Konselor sebaya pemula merupakan siswa/mahasiswa yang baru direkrut, belum mempunyai pengalaman melaksanakan tugasnya sebagai konselor sebaya. Konselor sebaya madya merupakan siswa/mahasiswa yang sudah bertugas menjadi konselor sebaya minimal selama satu semester, dan memiliki kinerja yang baik. Konselor teman sebaya senior adalah siswa/mahasiswa yang bertugas menjadi konselor sebaya selama lebih dari dua semester dan memiliki kinerja yang baik. Berdasarkan hasil penelitian, sebanyak 59\% responden penelitian ini memberikan jawaban baru akan memulai menjadi konselor sebaya. Responden lainnya, sebanyak $11 \%$ dan $27 \%$ merupakan konselor sebaya tingkat madya, dan $1 \%$ lainnya merupakan konselor sebaya senior.

Pembagian tingkat konselor sebaya juga berpengaruh terhadap tugas yang diemban oleh siswa/mahasiswa sebagai konselor sebaya (Pandang, 2019). Tugas dari konselor sebaya pemula lebih banyak pada tugas-tugas administratif, pengumpulan data, dan pemberian informasi. Konselor sebaya tingkat madya memiliki tugas tambahan lainnya, seperti dapat melakukan layanan prakonseling untuk menyelesaikan masalah pribadi dan sosial yang ringan, dan dapat menjadi tenaga bantu dalam kaderisasi konselor sebaya yang baru. Bagi siswa/mahasiswa sebagai konselor sebaya tingkat senior, bertugas melakukan layanan prakonseling dalam menyelesaikan masalah interpersonal dan intrapersonal yang ringan. Selain itu, konselor sebaya tingkat senior juga dapat diikutsertakan dalam pelatihan konselor sebaya baru dan menjadi co-leader dalam konseling ataupun bimbingan kelompok. Pada masa pandemi covid-19, konseling sebaya dalam dilakukan secara online melalui Zoom, Google Meet, Whatsapp Grup, Edmodo, dan aplikasi berbasis online lainnya (Ifdil et al., 2017).

Latar belakang atau alasan remaja menjadi konselor sebaya merupakan potensi personal dan kompetensi dasar menjadi konselor yang berkualitas dan efektif. Potensi personal yang dimiliki oleh konselor sebagai cerminan konselor yang berkualitas (Hartini \& Ariana, 2016), yaitu: (1) ingin membantu individu lain; (2) bahagia jika individu lain dapat mengembangkan diri; (3) bahagia jika dapat menyebarkan cinta dan memberi semangat hidup bagi orang lain. Hal ini mendukung hasil penelitian ini, bahwa alasan remaja menjadi konselor sebaya adalah ingin dan senang bila dapat membantu teman dalam menyelesaikan masalahnya. Perasaan ingin membantu orang lain adalah motivasi utama yang harus dimiliki oleh seorang konselor sebaya. Ketulusan seseorang dalam menjalankan tugasnya sebagai konselor, akan dapat membantu terciptanya hubungan konseling yang efektif (Hartini \& Ariana, 2016).

Latar belakang tersebut juga menjadi indikator kualitas pribadi konselor sebaya yang terkait dengan motif-motif altruistik. Konselor merupakan pribadi terapeutik yang lebih mengedepankan nilai-nilai altruistik atau kepedulian terhadap orang lain, daripada nilai-nilai mementingkan diri sendiri (Corey, 2015). Motif-motif dan sikap positif untuk konseli akan mendorong terciptanya pribadi konselor yang efektif. Pribadi konselor yang efektif berperan besar dalam mendukung terciptanya layanan konseling yang efektif. Kamus Besar Bahasa Indonesia mengartikan altruistik sebagai kerelaan dalam menolong orang lain tanpa mengharapkan imbalan atau tanpa memperhatikan kepentingan sendiri. Hartini \& Ariana (2016) mendefinisikan altruistik sebagai semangat berkorban untuk menolong orang lain dan selalu mengedepankan aspek manusiawi dalam memberi pertolongan. Hal ini mendukung hasil penelitian ini, yaitu 53\% responden menganggap konselor teman sebaya memiliki 
kelebihan yaitu memiliki motivasi untuk membantu, yang artinya konselor sebaya memiliki motif-motif altruistik dalam menjalankan tugasnya.

Keterampilan dalam melakukan konseling terbagi menjadi dua, yaitu keterampilan eksternal dan internal, seperti keterampilan komunikasi, keterampilan bertindak, dan keterampilan berpikir (Azmi, 2018; Mulawarman \& Antika, 2020). Keterampilan eksternal merupakan keterampilan yang dapat diamati, berbentuk tindakan atau perilaku yang dilakukan oleh konselor (R.N. Jones, 2003). Keterampilan yang dapat diamati ini seperti keterampilan berkomunikasi secara verbal (pemilihan kata), keterampilan berbicara (volume, intonasi dan artikulasi), dan keterampilan mengatur bahasa tubuh (kontak mata, ekspresi wajah, posisi dan jarak tubuh). Keterampilan eksternal tersebut muncul didorong oleh keterampilan internal atau keterampilan berpikir (mind-skills). Keterampilan berpikir (mindskills/internal skills) merupakan proses mental konselor saat melakukan konseling (R.N. Jones, 2003).

Penguasaan mind-skills yang baik akan membuat konselor sebaya dapat memberikan layanan konseling yang efektif. Keterampilan berpikir ini dijabarkan menjadi enam komponen, yaitu menciptakan: (1) aturan, (2) persepsi; (3) wicara diri; (4) visual; (5) penjelasan; dan (6) pengharapan yang membantu (Azmi, 2018; Jones, 2003; Mulawarman \& Antika, 2020). Peraturan yang diciptakan oleh konselor akan bersifat luwes dan realistis. Peraturan yang dimaksud adalah peraturan tentang hubungan antara konseli dan konselor, sehingga konselor dapat menempatkan diri sesuai dengan porsinya (Sinaga, Haryadi, \& Mahfud, 2018). Peraturan yang diciptakan oleh konselor akan membuat konseli dan konselor memiliki hubungan yang efektif, sehingga dapat membantu mencapai tujuan konseling. Persepsi yang diciptakan oleh konselor merupakan persepsi yang positif, yang akan menimbulkan sikap positif, bahwa setiap masalah ada penyelesaiannya (Radjah, 2016). Persepsi positif konselor akan membantu konseli lebih optimis dalam menyelesaikan masalahnya. Self-talk (wicara diri) diciptakan oleh konselor untuk mengelola pikiran, sehingga konselor bisa menginstruksikan kepada dirinya sendiri mengenai apa yang akan dilakukannya, sehingga konseling dapat dilakukan dengan tepat (Jones, 2003). Wicara diri merupakan pengarah bagi tindakan konselor, mengenai apa yang harus dipikirkan dan dilakukan pada awal, pertengahan, dan akhir konseling.

Individu dapat meningkatkan kemampuan berpikirnya bila mendapat informasi berupa uraian kalimat dan juga visualisasi melalui gambar (Mulawarman \& Antika, 2020). Visual yang diciptakan oleh konselor dalam kepalanya, akan membantu dirinya dalam memetakan masalah dan alur pikir konseli dengan cepat dan tepat. Komponen penjelasan yang membantu dalam mind-skills bermaksud untuk memperjelas permasalahan yang sedang dihadapi konseli. Penjelasan yang dibuat dapat membantu konselor untuk mendiagnosa permasalahan konseli dengan tepat (Sinaga et al., 2018). Hal ini akan mendorong konselor untuk menciptakan pengharapan yang positif dan realistis untuk membantu konseli menyelesaikan masalahnya.

Hasil penelitian ini menunjukkan bahwa sebanyak $27 \%$ responden berpikir tentang apa yang bisa disarankan untuk konseli dan 24\% tentang apakah sebagai konselor dapat membantu konseli untuk menyelesaikan masalah. Hal ini terkait dengan komponen membuat penjelasan dan pengharapan yang membantu proses konseling. Konselor sebaya dapat menciptakan penjelasan yang membantu sehingga masalah yang konseli menjadi jelas, dan dapat menemukan solusi yang tepat bagi konseli. Pengharapan yang positif dari konselor terhadap dirinya sendiri, akan dapat menimbulkan keyakinan bahwa konselor sebaya dapat 
membantu konseli menyelesaikan masalahnya. Terutama dalam masa pandemi covid-19, komponen pengharapan merupakan komponen paling penting dalam proses konseling. Pengharapan konselor terhadap dirinya sendiri, dan pengharapan konselor terhadap masa depan konseli, dapat berdampak positif terhadap perasaan dan fisik konseli (Azmi, 2018).

Tindakan atau perilaku individu berasal dari dalam pikiran individu, yang merupakan konsekuensi dari apa yang dipikirkan dan bagaimana mengelola pikiran tersebut (R Nelson Jones, 2003). Hal ini tentu menegaskan bahwa keterampilan mengendalikan pikiran atau mindskills yang sudah dijelaskan sebelumnya, merupakan keterampilan utama yang harus dikuasai oleh konselor sebaya. Sejalan dengan hasil penelitian ini, responden sebanyak 54\% memilih keterampilan mengendalikan pikiran merupakan keterampilan yang ingin dipelajari atau dikuasai oleh konselor sebaya. Responden lainnya menjawab teknik-teknik dan prosedur konseling yang perlu dikuasai oleh konselor sebaya. Namun, perlu diingat kembali hakikat konseling sebaya yang diartikan sebagai berbagai kegiatan bantuan interpersonal oleh tenaga nonprofesional yang melaksanakan peran menolong sebaya dengan keterampilan komunikasi dan mendengar aktif (Tindall \& Black, 2011). Konselor sebaya membantu menyelesaikan permasalahan pribadi dan sosial yang sederhana (Pandang, 2019). Oleh karena itu, keterampilan utama yang diperlukan oleh konselor sebaya adalah keterampilan dasar komunikasi. Pandang (2019) mengemukakan, ada enam keterampilan dasar komunikasi yang memadai bagi konselor sebaya untuk memulai kegiatan konseling, meliputi (1) keterampilan penerimaan konseli; (2) keterampilan bertanya dan mengawali percakapan; (3) keterampilan memparaphrase; (4) keterampilan empati; (5) keterampilan menyimpulkan; dan (6) keterampilan problem solving.

\section{Simpulan}

Di masa pandemi covid-19, konselor sebaya dapat berperan cukup baik membantu teman seusianya untuk dalam menghadapi permasalahan psikologis akibat dampak dari pandemi ini. Gambaran remaja menjadi konselor sebaya di masa pandemic covid-19 yang dihadapkan oleh peneliti adalah pada rentang usia 15-20 tahun dengan tingkat pendidikan SMP sampai SMA, Konselor sebaya tingkat pemula. Sementara yang menjadi latar belakang menjadi konselor sebaya adalah keinginan membantu dan merasa senang jika dapat membantu konseli menyelesaikan masalah, motivasi untuk membantu dan menjadi pendengar yang baik menjadi pilihan responden, dan keterampilan yang diharapkan dimiliki konselor sebaya adalah keterampilan berpikir atau mind-skills.

\section{Daftar Rujukan}

Azmi, K. R. (2018). Keterampilan berpikir (mind skills) pada proses konseling: kajian dalam perkembangan kognitif neurosains. KONSELING EDUKASI“Journal of Guidance and Counseling," 2(1).

Barbara Russell, M. B. A. (2010). Influenza pandemic, mental illnesses, addictions. Journal of Ethics in Mental Health, 5(1), 1-5.

Carandang, R. R., Shibanuma, A., Kiriya, J., Vardeleon, K. R., Marges, M. A., Asis, E., ... Jimba, M. (2019). Leadership and peer counseling program: Evaluation of training and its impact on Filipino senior peer counselors. International Journal of Environmental Research and Public Health, 16(21), 4108.

Chafouleas, S. M., \& Marcy, H. M. (2020). Responding to COVID-19: Planning for trauma-informed assessment in schools.

Corey, G. (2009). Teori dan praktek konseling dan psikoterapi. Bandung: PT Refika Aditama.

Corey, G. (2015). Theory and practice of counseling and psychotherapy [BOOK]. Nelson Education.

Hartini, N., \& Ariana, A. D. (2016). Psikologi konseling: Perkembangan dan penerapan konseling dalam psikologi. Airlangga University Press. 
Hendrik, H., \& Elmansyah, T. (2018). Meningkatkan keterampilan interpersonal melalui konseling teman sebaya Sekolah Menengah Atas Negeri 1 Segedong. JBKI (Jurnal Bimbingan Konseling Indonesia), 3(1), $22-26$.

Hurlock, E. B. (2005). Psikologi perkembangan: Suatu pendekatan sepanjang rentang kehidupan. Jakarta: Erlangga.

Husein, F. (2018). Pengembangan model peer counseling "maju bersama" untuk meningkatkan perilaku prososial siswa di SMK Penerbangan AAG Adisutjipto Yogyakarta.

Ifdil, I., Ilyas, A., Churnia, E., Erwinda, L., Zola, N., Fadli, R. P., ... Refnadi, R. (2017). Pengolahan Alat Ungkap Masalah (AUM) dengan menggunakan komputer bagi konselor. Jurnal Aplikasi IPTEK Indonesia, 1(1), $17-24$.

Indriyati, F. N. (2018). Pelaksanaan konseling sebaya (peer counseling) untuk membantu penerimaan diri pada penderita lupus di Yayasan Tittari Surakarta. Institut Agama Islam Negeri Surakarta.

Ismiyati, I., Walessa, R., Sunjaya, D. K., \& Susanah, S. (2019). Model modul konseling sebaya tentang kesehatan reproduksi remaja. Jurnal Medikes (Media Informasi Kesehatan), 6(2), 273-286.

Jones, R. N. (2003). Basic counseling skills: A helper's manual. London: Sage Publications.

Jones, R. N. (2003). Introduction to counseling skills. Text \& Activities.

Kandah, C. C. (2017). The use of peer counselors and narrative exposure therapy with african refugees and Ugandan Nationals: An evaluation of program feasibility and preliminary effectiveness. Rosalind Franklin University of Medicine and Science.

Kar, S. K., Arafat, S. M. Y., Sharma, P., Dixit, A., Marthoenis, M., \& Kabir, R. (2020). COVID-19 pandemic and addiction: Current problems and future concerns. Asian Journal of Psychiatry, 51, 102064.

Kemenkes RI. (2013). RISKESDAS 2013.

Laila, S. N., Flurentin, E., \& Simon, I. M. (2019). Development of Peer Counselor Training Manual at State University of Malang. 5th International Conference on Education and Technology (ICET 2019), 39-42. Atlantis Press.

Minkos, M. L., \& Gelbar, N. W. (2021). Considerations for educators in supporting student learning in the midst of COVID-19. Psychology in the Schools, 58(2), 416-426.

Mulawarman, M., \& Antika, E. R. (2020). Mind-skills konsep dan aplikasinya dalam praktik konseling. Jakarta: Kencana.

O’Sullivan, T., \& Bourgoin, M. (2010). Vulnerability in an influenza pandemic: Looking beyond medical risk. Behaviour, 11, 16.

Pandang, A. (2019). Program konseling teman sebaya di sekolah. Bogor: Graha Cipta Media.

Pragholapati, A. (2020). COVID-19 impact on students.

Prasetiawan, H. (2016). Konseling teman sebaya (peer counseling) untuk mereduksi kecanduan game online. Counsellia: Jurnal Bimbingan Dan Konseling, 6(1), 1-13.

Radjah, C. L. (2016). Keterampilan konseling berbasis metakognisi. Jurnal Kajian Bimbingan Dan Konseling, 1(3), 90-94. https://doi.org/10.17977/um001v1i32016p090

Rahmawati, A. H., \& Suwarjo, H. B. U. (2019). The effect of basic skills counseling as vital skills in peer counseling to Indonesian Students. Universal Journal of Educational Research, 7(9), 1874-1881.

Salmiati, S., Rosmawati, R., \& Lestari, M. (2018). Peer Counselor Training Untuk Mencengah Perilaku Bullying. Indonesian Journal of Learning Education and Counseling, 1(1), 62-69.

Santrock, J. W. (2007). Perkembangan anak. Jakarta: Erlangga.

Sari, N. P. (2017). Pengembangan modul pelatihan konseling teman sebaya untuk anggota pmr di smp negeri 1 banjarmasin. Proceeding Seminar dan Lokakarya Nasional Bimbingan Dan Konseling 2017, 1, 167-178.

Sarmin, S. (2017). Konselor Sebaya: Pemberdayaan Teman Sebaya dalam Sekolah Guna Menanggulangi Pengaruh Negatif Lingkungan. Briliant: Jurnal Riset dan Konseptual, 2(1), 102-112.

Schmidt, J. G. (2013). Counseling in schools: Comprehensive programs of responsive services for all students. Pearson Higher Ed. 
Buletin Konseling Inovatif/Bulletin of Innovative Counseling, 1(1), 2021, 32-44

Sinaga, M. H. F., Haryadi, R., \& Mahfud, A. (2018). Mengatasi Permasalahan yang Dihadapi Oleh Konselor Pemula dengan Menggunakan Mind Skills. Prosiding Online Dalam Seminar Dan Workshop Bimbingan Dan Konseling.

Soerachman, R. (2007). Global school-based health survey.

Syarifah, Y. R. N. (2020). Implementasi konselor sebaya teman sehati pada masa pandemi Covid-19 di P4K IAIN Purwokerto. IAIN Purwokerto.

Tindall, J. A., \& Black, D. R. (2011). Peer programs: An in-depth look at peer programs: Planning, implementation, and administration. Routledge.

Upcraft, M. L. (1971). Undergraduate students as academic advisers. The Personnel and Guidance Journal, 49(10), 827-831.

WHO. (2014). Health for the world's adolescents. Retrieved from http://www.searo.who.int/indonesia/documents/health-for-worldadolescent-who-fwc-mca-14.05eng.pdf?ua $1 / 41$

WHO. (2020). Coronavirus disease (COVID-19) outbreak situation. Coronavirus Dis. COVID-19 Pandemic. Retrieved from https://www.who.int/emergencies/diseases/novel-coronavirus-2019

Yao, H., Chen, J.-H., \& Xu, Y.-F. (2020). Rethinking online mental health services in China during the COVID-19 epidemic. Asian Journal of Psychiatry, 50, 102015. 